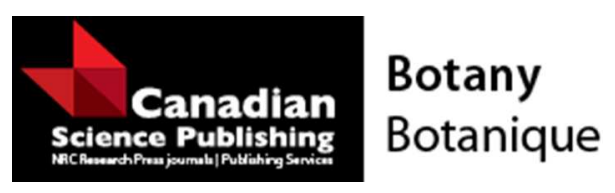

\title{
Effects of winter warming on cold hardiness and spring budbreak of four boreal conifers
}

\begin{tabular}{|r|l|}
\hline Journal: & Botany \\
\hline Manuscript ID & cjb-2015-0181.R1 \\
\hline Danuscript Type: & Article \\
\hline Complete List of Authors: & $\begin{array}{l}\text { Man, Rongzhou; Ontario Ministry of Natural Resources } \\
\text { Colombo, Steve; Ontario Ministry of Natural Resources, } \\
\text { Lu, Pengxin; Ontario Forest Research Institute } \\
\text { Dang, Qing-Lai; Lakehead University, Faculty of Natural Resources } \\
\text { Management }\end{array}$ \\
\hline Keyword: & \begin{tabular}{l} 
winter freezing, dehardening, rehardening, pine and spruce seedlings \\
\hline
\end{tabular} \\
\hline
\end{tabular}

SCHOLARONE $^{\text {tw }}$
Manuscripts 
Effects of winter warming on cold hardiness and spring budbreak of four boreal conifers

Rongzhou Man ${ }^{1 *}$, Steve Colombo ${ }^{1,2}$, Pengxin Lu ${ }^{1}$, and Qing-Lai Dang ${ }^{3}$

${ }^{1}$ Ontario Ministry of Natural Resources and Forestry, Ontario Forest Research Institute, 1235

Queen Street East, Sault Ste. Marie, ON, Canada P6A 2E5 rongzhou.man@ontario.ca;

steve.colombo@ontario.ca; pengxin.lu@ontario.ca

${ }^{2}$ Current address: EcoView, 163 Arlington Boulevard, Tecumseh, ON N8N 2J6

Ecoviewconsulting@gmail.com

${ }^{3}$ Faculty of Natural Resources Management, Lakehead University, Thunder Bay, ON P7B 5E1 qdang@lakeheadu.ca

*Corresponding author (phone: 705-946-7484; Fax: 705-946-2030; email:

rongzhou.man@ontario.ca) 


\begin{abstract}
Compared to spring frosts on opening buds or newly flushed tissues, winter freezing damage on conifers, due to temperature fluctuations prior to budbreak, is rare and less known. In this study, changes in cold hardiness (measured based on electrolyte leakage and needle damage) and spring budbreak were assessed to examine the responses of four boreal conifer species black spruce (Picea mariana (Mill.) B.S.P.), white spruce (Picea glauca) (Moench) Voss), jack pine (Pinus banksiana Lamb.), and lodgepole pine (Pinus contorta Dougl. ex. Loud.) - to different durations of experimental warming $\left(16^{\circ} \mathrm{C}\right.$ day $/-2{ }^{\circ} \mathrm{C}$ night with 10 -h-photoperiod, except for night temperature in November warming $\left.\left(+2{ }^{\circ} \mathrm{C}\right)\right)$. Seedlings showed increased responses to the warming from November to March, while the capacity to regain the cold hardiness lost to warming decreased during the same period. This suggests an increasing vulnerability of conifers to temperature fluctuations and freezing damage with the progress of chilling fulfilment and dormancy release from fall to spring. Both lodgepole pine and jack pine initiated spring growth earlier and had greater responses to experimental warming in bud phenology than black spruce and white spruce, suggesting a greater potential risk of frost/freezing damage to pine trees in the spring.
\end{abstract}

Key words: winter freezing, dehardening, rehardening, pine and spruce seedlings 


\section{Introduction}

Global temperatures are expected to continue to rise under the predicted change of climate (Christensen et al. 2007). The climatic warming, however, will not be uniform, generally greater at higher latitudes and in winter months (Bonsol et al. 2001; Shabbar and Bonsal 2003; Robeson 2004; Christensen et al. 2007). As temperature is the primary factor controlling dehardening and budbreak in the spring (Kramer 1994; Saxe et al. 2001), the expected warming may hasten spring dehardening and budbreak, extend the growing season, and increase growth (Badeck et al. 2004; Schwartz et al. 2006; Delbart et al. 2008; Gunderson et al. 2012). All these changes can increase productivity and carbon sequestration in the boreal forests (Myneni et al. 1997; Euskirchen et al. 2006; Bronson et al. 2009), where growth is generally limited by low temperatures (Keyser et al. 2000; Bronson et al. 2009).

However, the consequences of warming can be quite different if increases in temperatures are associated with greater variability, as suggested by Cannell and Smith (1986), Hänninen (1991), Man et al. (2009), and Augspurger (2013). Late spring frosts can damage expanding buds or newly flushed tissues (Hiratsuka and Zalasky 1993). Freezing damage can also occur before budbreak when trees that are dehardened during warm spells in winter months are subsequently exposed to seasonal cold days (Cayford et al. 1959; Sakai and Larcher 1987; Perkins and Adams 1995; Bokhorst et al. 2008; Man et al. 2009, 2013). Such winter freezing is generally extensive, affecting trees of all sizes and species in large areas (Cayford et al. 1959; Hiratsuka and Zalasky 1993; Man et al. 2009, 2013) and leading to growth loss and mortality (Bella and Navratil 1987; Man et al. 2013), especially in conifers that carry multi-year foliage (Man et al. 2013). Compared with damage by spring frosts that are common in boreal regions 
(Dang et al. 1992; Hiratsuka and Zalasky 1993), damage from winter freezing is relatively rare and has not been adequately studied (Hiratsuka and Zalasky 1993; Man et al. 2009, 2013).

Unlike spring frosts where damaged flushing tissues quickly change colour and are easily visible, the freezing damage in winter months is not immediately obvious due to low metabolism of dormant trees and preservation of damaged needles, shoots, and buds in cold conditions such that damage is often not noticed until several months later in spring or early summer when damaged trees show abnormal growth or needle discoloration and mortality (van der Kamp and Worrall 1990; Man et al. 2009, 2013). Because of a lack of understanding of dehardening processes and the common belief that boreal trees are hardy enough to resist winter cold, winter freezing can be misdiagnosed as winter desiccation, root freezing, or winter embolism (Man et al. 2009, 2013).

Black spruce (Picea mariana (Mill.) B.S.P.), white spruce (Picea glauca (Moench) Voss), jack pine (Pinus banksiana Lamb.), and lodgepole pine (Pinus contorta Dougl. ex. Loud.) are four widely distributed conifers in North American boreal forests (Rowe 1972). These species have adapted to the boreal climate over thousands of years (Natural Resources Canada 2005) and have evolved to synchronize the timing of life-cycle events with the annual cycle of the environment: growth cessation and dormancy are cued by shortening photoperiod in late summer; a certain duration of cold conditions in the fall and winter is needed to break dormancy; and a certain accumulation of thermal units in the spring is required to break buds (Saxe et al. 2001). In boreal regions, the winter is long and chilling requirements are met early in the year (Colombo 1998; Hannerz et al. 2003; Linkosalo et al. 2006), so that trees are ready to grow as soon as favorable conditions (mainly temperature) occur. Normally, the accumulation of thermal units for dehardening and budbreak occur in parallel with the gradual rise of temperatures in the 
spring (Saxe et al. 2001). However, increasing asynchronization may occur if trees deharden earlier because of warm temperatures and subsequently face damaging cold weather, as a consequence of climatic warming (Bokhorst et al. 2008; Man et al. 2009; Augspurger 2013). Three cases of large-scale winter dehardening-freezing damage in central Canada have been reported: 1958 in Saskatchewan, Manitoba and northwestern Ontario (Buchan 1958; Cayford et al. 1959), 2007 in northeastern Ontario (Man et al. 2009), and 2012 in northwestern Ontario (Man et al. 2013). The red belt damage that often affects lodgepole pine and other conifers in western Canada in the Rocky Mountains of Alberta and British Columbia (Robin and Susut 1974; Bella and Navratil 1987; Hiratsuka and Zalasky 1993) could also be attributable to winter dehardening-freezing (Robin and Susut 1974; Man et al. 2013).

The objective of this study was to examine the responses of cold hardiness and spring budbreak in black spruce, white spruce, jack pine, and lodgepole pine to different durations of simulated warming in different winter months. We hypothesized that (1) exposure to warm temperatures in winter months would reduce cold hardiness of trees and hasten spring budbreak, (2) the levels of response would vary by species (different chilling and thermal requirements) and season (before and after fulfillment of chilling requirements), and (3) dehardened trees would regain some of the cold hardiness lost to warming when being returned to non-freezing winter conditions.

\section{Materials and methods}

\section{Seedlings}

Container seedlings of lodgepole pine were initially raised in the greenhouse of the Tree Time Services Inc./Coast to Coast Reforestation at Smoky Lake, Alberta, using seeds of open- 
pollinated wild trees from southwest of Whitecourt, Alberta, Canada $\left(54^{\circ} 04^{\prime} \mathrm{N}, 116^{\circ} 41^{\prime} \mathrm{W}\right)$.

Container seedlings of black spruce, white spruce and jack pine were initially grown at the Millson Forestry Service Inc. in Timmins, Ontario, using seeds from orchard trees established for the Martel Forest area $\left(47^{\circ} 50^{\prime}-48^{\circ} 28^{\prime} \mathrm{N}, 82^{\circ} 15^{\prime}-83^{\circ} 25^{\prime} \mathrm{W}\right)$. One-year-old container seedlings of the above species were subsequently shipped to Sault Ste. Marie, Ontario, in early June of 2013 for use in this study. Upon arrival, the seedlings were transplanted into 4" square pots $(10 \mathrm{~cm}$ side $\mathrm{x} 15 \mathrm{~cm}$ deep) filled with $2: 1$ peat moss/vermiculite $(v / v)$ mixture and grown in the greenhouse at the Ontario Forest Research Institute in Sault Ste. Marie, Ontario. The seedlings received natural photoperiods with temperatures 2 to $5^{\circ} \mathrm{C}$ above ambient. Seedlings were watered as required and fertilized weekly with 20-8-20 (N-P-K) (Plant Products Co Ltd, Brampton, $\mathrm{ON}$ ) at $100 \mathrm{ppm} \mathrm{N}$ for a month before being moved outdoors in early July. Watering and fertilization continued as required until early September when fertilization was adjusted to 20-20-20 at $50 \mathrm{ppm} \mathrm{N}$ and the fertilization was discontinued in mid-October.

The average height and basal diameter of the seedlings prior to warming treatments were $27.7 \mathrm{~cm}$ and $5.0 \mathrm{~mm}$ for white spruce, $35.9 \mathrm{~cm}$ and $4.8 \mathrm{~mm}$ for black spruce, $22.6 \mathrm{~cm}$ and 5.2 $\mathrm{mm}$ for jack pine, and $23.9 \mathrm{~cm}$ and $5.8 \mathrm{~mm}$ for lodgepole pine, respectively.

\section{Warming treatments}

Different groups of seedlings received experimental warming treatments at one of the three time segments between November 2013 and March 2014. November warming was applied between November 10 and 25 when chilling requirements for dormancy release were not expected to be fully met (Colombo 1998; Tanja et al. 2003; Søgaard et al. 2008). During the January warming period (January 10 to 25), it was suspected that the chilling requirements were largely or 
completely met but that thermal accumulation for budbreak had not started due to low temperature in Sault Ste Marie, Ontario (Fig. 1). Finally, during the March warming period (March 10 to 25) it was expected that seedlings have begun to accumulate thermal units for budbreak and entered a period of susceptibility to freezing damage due to loss of cold hardiness (Cayford et al. 1959; Augspurger 2013; Man et al. 2009, 2013). At each warming period, 8 seedlings of each species received one of four warming treatments: warming for 5-, 10-, or 15days or a control (left outside) with no warming. The warming levels were chosen to approximate $15 \%, 30 \%$, and $50 \%$ of the thermal units for budbreak required by white spruce (Man and Lu 2010), a species that may need the least thermal units to break buds among the four boreal conifers (Man et al. 2009). Each of the warming treatments was replicated 3 times with different groups of seedlings (8 seedlings within each replication). At each warming period seedlings were removed from outdoors into a greenhouse set at $16{ }^{\circ} \mathrm{C}$ (day) $/-2{ }^{\circ} \mathrm{C}$ (night), a 10 hour photoperiod at $350 \mu \mathrm{mol} \mathrm{m} \mathrm{m}^{-2}$ photosynthetic photon flux density (PPFD), and 50\% humidity, except for the fall warming period in which night temperature was set at $2{ }^{\circ} \mathrm{C}$ to reflect higher ambient night temperatures (Fig. 1). These temperatures were chosen according to historical winter warming/freezing events in later winter and early spring in boreal forests (Cayford et al. 1959; Man et al. 2009, 2013). The starting dates of the warming treatments with the three durations were arranged so that all the treatments ended on the same day. Prior to warming treatments in the winter and spring warming periods, seedlings were kept at $-4{ }^{\circ} \mathrm{C}$ overnight when the ambient temperatures were below $-10{ }^{\circ} \mathrm{C}$ to minimize temperature shock. At the end of warming treatments all seedlings, including those left in ambient conditions (control, no warming), were bagged and stored at $-4{ }^{\circ} \mathrm{C}$. 


\section{Cold hardiness and budbreak assessments}

Changes in seedling cold hardiness after warming were evaluated using freeze-induced electrolyte leakage (FIEL) by measuring the electrical conductivity of water in which tissues were immersed after freezing. Increased conductivity indicates freezing damage (Colombo et al. 1984). Pine needle fascicles and spruce shoot tips (with needles and buds) collected from laterals or lower main stems of the tested seedlings were frozen to one of four test temperatures, +4 (nonfreezing), $-15,-30$, and $-60{ }^{\circ} \mathrm{C}$. The tests were conducted immediately after the warming treatments and were repeated 10 and 20 days after cold storage at $-4{ }^{\circ} \mathrm{C}$ to determine if seedlings regained hardiness that may have been lost during warming treatments. For each freezing test, pine needles and spruce shoots collected from 6 seedlings were divided among test tubes in a way that each tube had six pine needle fascicles or 1-cm spruce shoot tips from 6 different seedlings. While the non-freezing samples remained in the refrigerator at $+4{ }^{\circ} \mathrm{C}$ during the freezing tests, other samples were subjected to freezing temperatures in a programmable freezer (Thermotron ${ }^{\circledR}$ SM-32-C, Holland, MI). The temperature inside the freezer was first lowered to $0^{\circ} \mathrm{C}$ in one hour, held at $0^{\circ} \mathrm{C}$ for $1 \mathrm{~h}$ for equilibration, and was then lowered at a rate of $5{ }^{\circ} \mathrm{C} \mathrm{h}^{-1}$, until the temperature inside the test tubes (two thermocouples touching tissue samples) reached the target temperatures. Samples were then moved out of the freezer and thawed in a refrigerator at $+4{ }^{\circ} \mathrm{C}$ overnight.

After thawing, $35 \mathrm{ml}$ of deionized water was added to each test tube, sufficient to submerge needles and shoot segments. The tubes were then sealed with transparent plastic and incubated in a growth chamber at $20^{\circ} \mathrm{C}$ and $200 \mu \mathrm{mol} \mathrm{m} \mathrm{m}^{-2}$ photosynthetic photon flux density (PPFD) for 5 days to enhance the release of diffusible electrolytes from damaged tissues (Deans et al. 1995) and facilitate the development of visual signs of damage. The solution was measured 
to determine after-freezing electrical conductivity at $20^{\circ} \mathrm{C}$ using a Cole-Parmer conductivity meter (Cole-Parmer Instrument Company, Singapore). After 5 days the tissues were considered healthy if needles were green and the solution was clear, and damaged if needles turned yellowish and the solution was cloudy. The solutions and samples were then placed in a hot water bath at $90{ }^{\circ} \mathrm{C}$ for two hours, cooled to room temperature, and incubated at $+4{ }^{\circ} \mathrm{C}$ for 48 hours. The electrical conductivity after killing live tissues was measured at $20^{\circ} \mathrm{C}$ and used to calculate relative conductivity $(\mathrm{RC})$, the ratio of frozen or control conductivity to conductivity after killing (Colombo et al. 1984).

The spring budbreak and shoot elongation of seedlings after warming treatments were observed twice a day from early May under the greenhouse conditions of $20^{\circ} \mathrm{C}($ day $) / 10^{\circ} \mathrm{C}$ (night), a 16 hour photoperiod at $350 \mu \mathrm{mol} \mathrm{m} \mathrm{s}^{-2}$ photosynthetic photon flux density (PPFD), and $50 \%$ humidity. The time to budbreak of individual seedlings was determined as thermal units of cumulative growing degree hours above the threshold of $0^{\circ} \mathrm{C}$ (Snyder et al. 1999; Man and $\mathrm{Lu} 2010$ ) when spruce broke buds and pine started shoot elongation. Seedlings that had terminal damage were not included in the cumulative growing degree hour calculation. The total number of seedlings excluded was 3 for lodgepole pine, 2 for black spruce and 0 for jack pine and white spruce.

\section{Statistical analyses}

Relative conductivity data were analysed by individual warming period following a factorial experimental design of four warming treatments and four test temperatures. Budbreak data (cumulative growing degree hours) were analyzed for each species in a two-way factorial design of four warming treatments and three warming periods during the winter months. The 
experimental units in this analysis were the mean values of 8 seedlings under each treatment combinations. Normality based on graphical display and Shapiro-Wilk test on residuals for RC data was achieved using a log transformation. Multiple contrasts were conducted to examine differences among warming treatments at specific test temperatures or seasonal periods.

\section{Results}

\section{Cold hardiness}

Both relative conductivity $(\mathrm{RC})$ and needle damage increased with decreasing test temperatures, duration of warming treatment, and along the season from November to March (Table 1; Figs. 2, 3, and 4). Among the four conifers, the warming had slightly greater impacts on lodgepole pine in November and on white spruce in March, as shown by the difference between controls and the warming treatments. In January, the 4 tree species, however, responded similarly to warming treatments.

$\mathrm{RC}$ and needle damage generally decreased over time at $-4^{\circ} \mathrm{C}$ following warming in November and January (Table 1; Figs. 2, 3, and 4). In March, however, RC and needle damage remained largely the same after 20 days of cold storage at $-4^{\circ} \mathrm{C}$, particularly for jack pine (Table 1; Fig. 4).

Samples from control seedlings of all 4 species did not show visible needle damage even at $-60{ }^{\circ} \mathrm{C}$ test temperature in November and January, although the $\mathrm{RC}$ of lodgepole pine needles increased during cold storage at $-4^{\circ} \mathrm{C}$ in January warming (Figs. 2, 3, and 4). In March, however, only white spruce shoots of control seedlings appeared to be cold hardy at the $-60{ }^{\circ} \mathrm{C}$ test temperature. 


\section{Spring budbreak}

The cumulative growing degree hours for budbreak in control seedlings were about 6000 for black spruce, 4300 for white spruce and 1600 for jack pine and lodgepole pine, and were not statistically different from those exposed to warming in the fall (Table 1; Fig. 5). There was a trend of decreasing cumulative growing degree hours for budbreak with increasing warming in January and March, with significant treatment difference for jack pine in January and March warming and lodgepole pine in March warming. For all species, the cumulative growing degree hours required for budbreak in the spring budbreak experiment showed a decreasing trend from November to March warming (significant season effect).

\section{Discussion}

As predicted, winter warming reduced cold hardiness (increasing $\mathrm{RC}$ and needle damage) and promoted spring budbreak of boreal conifers. The degree of warming effects varied among tree species and the season, similar to the observations on boreal broadleaf species including trembling aspen (Populus tremuloides Michx.), balsam poplar (Populus balsamifera L.), and white birch (Betula papyrifera Marsh.) (Man et al. 2014). As in broadleaves, the impacts of warming increased from November to March, likely due to the fulfilment of chilling requirement for dormancy release (Colombo 1998; Tanja et al. 2003; Søgaard et al. 2008).

Studies show that after the fulfilment of chilling requirements, the cold hardiness of trees remains relatively stable within a certain range of daily minimum temperatures (Repo et al. 1990; Leinonen et al. 1997; Saxe et al. 2001) or varies within a certain degree of fluctuations (Sakai and Larcher 1987; Repo 1992) prior to the start of thermal unit accumulation for budbreak in the spring. Both situations occurred in this study as indicated by the cold hardiness of control 
seedlings in March (Fig. 4). The spring warming was applied in March when minimum temperatures were higher than in late January, but little thermal accumulation had taken place (Fig. 1). The cold hardiness of white spruce control seedlings in March stayed unchanged from the January level, similar to that observed by Man et al. (2014) in boreal broadleaves and the findings of Glerum (1973) in his comparison between white spruce and black spruce. This pattern is, however, different from the observations of Bigras and Margolis (1997) who showed that white spruce apical buds were less hardy than black spruce and jack pine. As reported by others (Jonsson et al. 1986; Nilsson 2001; Ögren 2001), lodgepole pine showed additional sensitivity to warming/temperature fluctuations in cold hardiness in November and January, supporting the linkage between winter freezing and red belt damage (Robin and Susut 1974; Man et al. 2013), which occurs more on lodgepole pine than on other conifers (Robin and Susut 1974). The greater sensitivity of lodgepole pine to warming/temperature fluctuations may have resulted from more rapid dehardening, lack of cold hardiness, or combination of both, as its thermal requirement for budbreak does not differ from that of jack pine (Fig. 5).

Our rehardening hypothesis was generally confirmed by the data of all the species and seasons. As suggested by Kalberer and Arora (2007) and Kalberer et al. (2007), dehardened trees can regain some of the cold hardiness lost due to warming, giving them the potential to reduce post-warming vulnerability to freezing. However, the rehardening capacity reduced from November to March, with progress of dormancy release and greater loss of cold hardiness caused by the warming treatments (Kalberer et al. 2006).

The response of RC to increasing warming was similar among the four species, although their thermal requirements for budbreak differed considerably (Fig. 5). This is due to the pattern of cold hardiness change during dehardening, with cold hardiness initially being lost more 
rapidly and becoming gradual with the further increase of thermal unit accumulation (Glerum 1973). Both lodgepole pine and jack pine did not initiate shoot elongation at the end of warming treatments between November and March, although thermal units accumulated during the 15-day warming treatment (from 2400 for January and March warming to 2820 for November warming) were greater than those needed for spring budbreak by control seedlings (1600, see Fig. 5). Nor did we see significant effects of January warming on lodgepole pine spring budbreak. This was possibly due to a continuous chilling into spring in the two pines (Man et al., unpublished data), as reported by Sloan (1991) for lodgepole pine and ponderosa pine (Pinus ponderosa Dougl. Ex Laws.) in Idaho.

Caution is required for the interpretation of the $\mathrm{RC}$ data measured in this study. The objective of the freezing tests was to compare the responses of seedlings among warming treatments on a relative basis, not to assess actual cold hardiness under natural conditions. Because of the short exposure duration of needle/shoots to test temperatures, the resulting RC would likely overestimate cold hardiness.

Although some of the differences between lodgepole pine and other conifers in their responses to winter warming may have resulted from the geographical distributions of the species (trees in higher latitudes/colder regions tend to have less chilling and thermal requirements for dormancy release and spring budbreak, see Howe et al. (2003)), our observations have two major implications. First, warming in winter reduces cold hardiness and shortens time to budbreak in the spring; some of the cold hardiness lost to warming may be regained in a non-freezing environment after warming (Man et al. 2014). The increasing responses to warming from November to March indicate increased sensitivity of boreal conifers to temperature variability and therefore vulnerability to freezing damage towards spring if 
warming is followed by cold periods (Cayford et al. 1959; Bokhorst et al. 2008; Man et al. 2009, 2013). The risk of this damage will become greater if temperature fluctuations increase with climatic warming, as suggested by Schär et al. (2004) and Rigby and Porporato (2008), especially during winter months (Bonsal et al. 2001; Robeson 2004; Augspurger 2013). Second, the quantitative data of thermal requirements for budbreak may provide reference for studies requiring such information in budbreak predictions and phenological modeling of these species, although more accurate results would be obtained through the quantification of heat accumulation on buds (Grace 2006). Our observations showed that lodgepole pine and jack pine initiated growth early in the spring (much earlier than white spruce, an early flushing boreal conifer, see O'Reilly and Parker (1982)). This difference is about 2 weeks with white spruce and 3 weeks with black spruce under spring conditions of $16^{\circ} \mathrm{C}$ day $/ 0^{\circ} \mathrm{C}$ night with 12 -hphotoperiod. Although earlier budbreak and growth in spring generally means a greater risk of frost/freezing damage (Cannell and Smith 1986; Man et al. 2009), it is unclear how the early growth initiation in pine would affect their cold hardiness and risk of freezing damage during spring dehardening, because of the differences between pine and spruce in spring bud and shoot phenology (Liepe 2014) and in their different responses to experimental warming (Fig. 5). Further work is required to link the cold hardiness of conifers to accumulation of thermal units and detailed changes of spring bud phenology and shoot growth, as shown by Bigras and Hébert (1996).

\section{Acknowledgements}

The authors thank Darren Derbowka and Kevin Maloney of the Ontario Ministry of Natural Resources and Forestry (OMNRF) for their assistance during the study, and Lisa Buse of 
OMNRF, the associate editor, and an anonymous reviewer for their constructive comments an earlier version of this manuscript. The lodgepole pine seedlings were provided by the Tree Time Services Inc./Coast to Coast Reforestation in Alberta and black spruce, white spruce and jack pine seedlings by the Millson Forestry Service Inc. in Ontario. 


\section{References}

Augspurger, C.K. 2013. Reconstructing patterns of temperature, phenology, and frost damage over 124 years: Spring damage risk is increasing. Ecology 94(1): 41-50.

Badeck, F.-W., Bondeau, A., Böttcher, K., Doktor, D., Lucht, W., Schaber, J., and Sitch, S. 2004. Responses of spring phenology to climate change. New Phytol. 162(2): 295-309.

Bella, I.E., and Navratil, S. 1987. Growth losses from winter drying (red belt damage) in lodgepole pine stands on the east slopes of the Rockies in Alberta. Can. J. For. Res. 17(10): $1289-1292$.

Bigras, F.J., and Hébert, C. 1996. Freezing temperatures and exposure times during bud break and shoot elongation influence survival and growth of containerized black spruce (Picea mariana) seedlings. Can. J. For. Res. 26(8): 1481-1489.

Bigras, F.J., and Margolis, H.A. 1997. Shoot and root sensitivity of containerized black spruce, white spruce and jack pine seedlings to late fall freezing. New For. 13(1): 29-49.

Bokhorst, S., Bjerkew, J.W., Bowlesz, F.W., Melilloz, J., Callaghan, T.V., and Phoenix, G.K. 2008. Impacts of extreme winter warming in the sub-arctic: growing season responses of dwarf shrub heathland. Glob. Change Biol. 14(11): 2603-2612.

Bonsal, B.R., Zhang, X., Vincent, L.A., and Hogg, W.D. 2001. Characteristics of daily and extreme temperatures over Canada. J. Climate 14(9): 1959-1976.

Bronson, D.R., Gower, S.T., Tanner, M., and van Herk, I. 2009. Effect of ecosystem warming on boreal black spruce bud burst and shoot growth. Glob. Change Biol. 15(6): 1534-1543.

Buchan, P.E. 1958. Status of insects and forest diseases in the western forest region. In Forest biology ranger district reports, Ontario. Edited by J.E. MacDonald. Forest Insect Laboratory. Victoria, BC. pp. 321-336.

Cannell, M.G.R., and Smith, R.I. 1986. Climatic warming, spring budburst and frost damage on trees. J. Appl. Ecol. 23(1): 177-191.

Cayford, J.H., Hildahl, V., Nairn, L.D., and Wheaton, M.P.H. 1959. Injury to trees from winter drying and frost in Manitoba and Saskatchewan in 1958. For. Chron. 35(4): 282-290.

Christensen, J.H., Hewitson, B., Busuioc, A., Chen, A., Gao, X., Held, I., Jones, R., Kolli, R.K., Kwon, W.-T., Laprise, R., Rueda, V.M., Mearns, L., Menéndez, C.G., Räisänen, J., Rinke, A., Sarr, A., and Whetton, P. 2007. Regional climate projections. In Climate Change 2007: The Physical Science Basis. Contribution of Working Group I to the Fourth Assessment 
Report of the Intergovernmental Panel on Climate Change. Edited by S. Solomon, D. Qin, M. Manning, Z. Chen, M. Marquis, K.B. Averyt, M. Tignor, and H.L. Miller. Cambridge University Press, Cambridge, UK and New York, USA. pp. 847-940.

Colombo, S.J. 1998. Climatic warming and its effect on bud burst and risk of frost damage to white spruce in Canada. For. Chron. 74(4): 567-577.

Colombo, S.J., Webb, D.P., and Glerum, C. 1984. Operational monitoring of frost hardiness for guiding the extended greenhouse culture method of hardening spruce container stock. Ontario Ministry of Natural Resources, For. Res. Rep. No. 110.

Dang, Q.L., Lieffers, V.J., and Rothwell, R.L. 1992. Effects of summer frosts and subsequent shade on foliage gas exchange in peatland tamarack and black spruce. Can. J. For. Res. 22(7): 973-979.

Deans, J.D., Billington, H.L., Harvey, F.J. 1995. Assessment of frost damage to leafless stem tissues of Quercus petraea: A reappraisal of the method of relative conductivity. Forestry 68(1): 25-34.

Delbart, N., Picard, G., Toan, T.L., Kergoat, L., Quegan, S., Woodward, I., Dye, D., and Fedotova, V. 2008. Spring phenology in boreal Eurasia over a nearly century time scale. Glob. Change Biol. 14(3): 603-614.

Euskirchen, E.S. , McGuire, A.D., Kicklighter, D.W., Zhuang, Q., Clein, J.S., Dargaville, R.J., Dye, D.G., Kimball, J.S., Mcdonald, K.C., Melillo, J.M., Romanovsky, V.E., and Smith, N.V. 2006. Importance of recent shifts in soil thermal dynamics on growing season length, productivity, and carbon sequestration in terrestrial high-latitude ecosystems. Glob. Change Biol. 12(4): 731-750.

Glerum, C. 1973. Annual trends in frost hardiness and electrical impedance for seven coniferous species. Can. J. Plant Sci. 53(4): 881-889.

Grace, J. 2006. The temperature of buds may be higher than you thought. New Phytol. 170(1): $1-3$.

Gunderson, C.A., Edwards, N.T., Walker, A.V., O'Hara, K.H., Campion, C.M., and Hanson, P.J. 2012. Forest phenology and a warmer climate - growing season extension in relation to climatic provenance. Glob. Change Biol. 18(6): 2008-2025.

Hannerz, M., Ekberg, I., and Norell, L. 2003. Variation in chilling requirements for completing bud rest between provenances of Norway spruce. Silvae Genet. 52(3-4): 161-168. 
Hänninen, H. 1991. Does climatic warming increase the risk of frost damage in northern trees? Plant Cell Environ. 14(5): 449-454.

Hiratsuka, Y., and Zalasky, H. 1993. Frost and other climate-related damage of forest trees in the Prairie Provinces. For. Can., North. For. Cent, Edmonton, Alta. Inf. Rep. NOR-X-331.

Howe, G.T., Aitken, S.N., Neale, D.B., Jermstad, K.D., Wheeler, N.C., and Chen, T.H.H. 2003. From genotype to phenotype: unraveling the complexities of cold adaptation in forest trees. Can. J. Bot. 81(12): 1247-1266.

Kalberer, S.R., and Arora, R. 2007. Cold hardiness of floral buds of deciduous azaleas: dehardening, rehardening, and endodormancy in late winter. J. Am. Soc. Hortic. Sci. 132(1): 73-79.

Kalberer, S.R., Leyva-Estrada, N., Krebs, S.L., and Arora, R. 2007. Frost dehardening and rehardening of floral buds of deciduous azaleas are influenced by genotypic biogeography. Environ. Exp. Bot. 59(3): 264-275.

Kalberer, S.R., Wisniewski, M., and Arora, R. 2006. Deacclimation and reacclimation of cold-hardy plants: current understanding and emerging concepts. Plant Sci. 171(1): 3-16.

Keyser, A.R., Kimball, J.S., Nemani, R.R., and Running, S.W. 2000. Simulating the effects of climate change on the carbon balance of North American high-latitude forests. Glob. Change Biol. 6(S1): 185-195.

Kramer, A. 1994. A modelling analysis of the effects of climatic warming on the probability of spring frost damage to tree species in the Netherlands and Germany. Plant Cell Environ. 17(4): 367-377.

Jonsson, A., Eriksson, G., and Franzen, A. 1986. Within-population variation in frost damage in Pinus contorta Dougl. seedlings after simulated autumn and late-winter conditions. Silvae Genet. 35(2/3): 96-102.

Leinonen, I., Repo, T., and Hänninen, H. 1997. Changing environmental effects on frost hardiness of scots pine during dehardening. Ann. Bot. 79(2): 133-138.

Liepe, K.J. 2014. Genetic variation in lodgepole pine and interior spruce: adaptation to climate and implications for seed transfer. Master thesis, University Alberta.

Linkosalo, T., Häkkinen, R., and Hänninen, H. 2006. Models of the spring phenology of boreal and temperate trees: is there something missing? Tree Physiol. 26(9): 1165-1172. 
Man, R., Colombo, S., Kayahara, G.J., Duckett, S., Velasquez, R., and Dang, Q.L. 2013. A case of extensive conifer needle browning in northwestern Ontario in 2012: Winter drying or freezing damage? For. Chron. 89(5): 675-680.

Man, R., Colombo, S., Lu, P., Li, J., and Dang, Q.L. 2014. Trembling aspen, balsam poplar, and white birch respond differently to experimental warming in winter months. Can. J. For. Res. 44(12): 1469-1476.

Man, R., Kayahara, G.J., Dang, Q.L., and Rice, J.A. 2009. A case of severe frost damage prior to budbreak in young conifers in northeastern Ontario: Consequence of climate change? For. Chron. 85(3): 453-462.

Man R, and Lu, P. 2010. Effects of thermal model and base temperature on estimates of thermal time to bud break in white spruce seedlings. Can. J. For. Res. 40(9): 1815-1820.

Myneni, R.B., Keeling, C.D., Tucker, C.J., Asrar, G., and Nemani, R.R. 1997. Increased plant growth in the northern high latitudes from 1981 to 1991. Nature 386(6626): 698-702.

Natural Resources Canada. 2005. The State of Canada's Forests 2004-2005: The boreal forest. Ottawa.

Nilsson, J.-E. 2001. Seasonal changes in phenological traits and cold hardiness of F1populations f rom plus-trees of Pinus sylvestris and Pinus contorta of various geographical origins. Scand. J. For. Res. 16(1): 7-20.

Ögren, E. 2001. Effects of climatic warming on cold hardiness of some northern woody plants assessed from simulation experiments. Physiol. Plant. 112(1): 71-77.

O’Reilly, C., and Parker, W.H. 1982. Vegetative phenology in a clonal seed orchard of Picea glauca and Picea mariana in northwestern Ontario. Can. J. For. Res. 12(2): 408-413.

Perkins, T.D., and Adams, G.T. 1995. Rapid freezing induces winter injury symptomatology in red spruce foliage. Tree Physiol. 15(4): 259-266.

Repo, T. 1992. Seasonal changes of frost hardiness in Picea abies and Pinus sylvestris in Finland. Can. J. For. Res. 22(12): 1949-1957.

Repo, T., Mäkelä, A., and Hänninen, H. 1990. Modelling frost resistance of trees. In Modelling to understand forest functions. Edited by H. Jozefek. Silva Carelica 15: 61-74.

Rigby, J.R., and Porporato, A. 2008. Spring frost risk in a changing climate. Geophys. Res. Lett. 35(12): L12703. 
Robeson, S.M. 2004. Trends in time-varying percentiles of daily minimum and maximum temperature over North America. Geophys. Res. Lett. 31(4): art. no. L04203.

Robin, J.K., and Susut, J.P. 1974. Red belt in Alberta. Can. For. Serv., Edmonton, AB. Inf. Rep. NOR-X-99.

Rowe, J.S. 1972. Forest regions of Canada. Can. For. Serv., Ottawa, Ont. Publ. No. 1300.

Sakai, A., and Larcher, W. 1987. Frost Survival of Plants: Responses and Adaptation to Freezing Stress. Springer-Verlag, New York, N.Y., USA.

Saxe, H., Cannell, M.G.R., Johnsen, Ø., Ryan, M.G., and Vourlitis, G. 2001. Tree and forest functioning in response to global warming. New Phytol. 149(3): 369-399.

Schär, C., Vidale, P.L., Lüthi, D., Frei, C., Häberli, C., Liniger, M.A., and Appenzeller, C. 2004. The role of increasing temperature variability in European summer heat waves. Nature 427(6972): 332-336.

Shabbar, A., and Bonsal, B. 2003. An assessment of changes in winter cold and warm spells over Canada. Nat. Hazards 29(2): 173-188.

Schwartz, M.D., Ahas, R., and Aasa, A. 2006. Onset of spring starting earlier across the Northern Hemisphere. Glob. Change Biol. 12(2): 343-351.

Sloan, J.P. 1991. Ponderosa and lodgepole pine seedlings bud burst varies with lift date and cultural practices in Idaho nursery. USDA Intermountain Research Station. Research note INT-391.

Snyder, R.L., Spano, D., Cesaraccio, C., and Duce, P. 1999. Determining degree day thresholds from field observations. Int. J. Biometeorol. 42(4): 177-182.

Søgaard, G., Johnsen, Ø., Nilsen, J., and Junttila, O. 2008. Climatic control of bud burst in young seedlings of nine provenances of Norway spruce. Tree Physiol. 28(2): 311-320.

Tanja, S., Berninger, F., Vesala, T., Markkanen, T., Hari, P., Mäkelä, A., Ilvesniemi, H., Hänninen, H., Nikinmaa, E., Huttula, T., Laurila, T., Aurela, M., Grelle, A., Lindroth, A., Arneth, A., Shibistova, O., and Lloyd, J. 2003. Air temperature triggers the recovery of evergreen boreal forest photosynthesis in spring. Glob. Chang. Biol. 9(10): 1410-1426. van der Kamp, B.J., and Worrall, J. 1990. An unusual case of winter bud damage in British Columbia interior conifers. Can. J. For. Res. 20(10): 1640-1647. 
Table 1. Probability values from ANOVA for relative conductivity and time to budbreak in spring under four treatments (5-, 10-, or 15-day warming or a control left outside) in three seasons (November, January, and March). Relative conductivity measurements were carried out at four test temperatures $\left(-60,-30,-15\right.$, and $+4{ }^{\circ} \mathrm{C}$ ) and three times (immediately, and 10 and 20 days after warming).

\begin{tabular}{|c|c|c|c|c|}
\hline \multirow[t]{2}{*}{ Treatment } & \multicolumn{4}{|c|}{ Tree species } \\
\hline & Black spruce & White spruce & Jack pine & Lodgepole pine \\
\hline \multicolumn{5}{|c|}{ Relative conductivity (November warming) } \\
\hline Time & 0.014 & $<0.001$ & $<0.001$ & $<0.001$ \\
\hline Warm & 0.010 & 0.001 & 0.009 & $<0.001$ \\
\hline Time*Warm & 0.347 & 0.224 & 0.473 & 0.001 \\
\hline Temperature & $<0.001$ & $<0.001$ & $<0.001$ & $<0.001$ \\
\hline Time*Temp & 0.024 & 0.006 & $<0.001$ & $<0.001$ \\
\hline Warm*Temp & 0.045 & 0.114 & 0.004 & $<0.001$ \\
\hline Time*Warm*Temp & 0.603 & 0.699 & 0.122 & 0.052 \\
\hline \multicolumn{5}{|c|}{ Relative conductivity (January warming) } \\
\hline Time & $<0.001$ & $<0.001$ & 0.023 & 0.004 \\
\hline Warm & $<0.001$ & $<0.001$ & $<0.001$ & 0.004 \\
\hline Time*Warm & 0.009 & 0.001 & 0.001 & $<0.001$ \\
\hline Temperature & $<0.001$ & $<0.001$ & $<0.001$ & $<0.001$ \\
\hline Time*Temp & 0.002 & 0.074 & 0.224 & $<0.001$ \\
\hline Warm*Temp & $<0.001$ & $<0.001$ & 0.597 & 0.022 \\
\hline Time*Warm*Temp & 0.074 & 0.076 & 0.923 & 0.010 \\
\hline \multicolumn{5}{|c|}{ Relative conductivity (March warming) } \\
\hline Time & $<0.001$ & 0.001 & 0.303 & $<0.001$ \\
\hline Warm & $<0.001$ & $<0.001$ & $<0.001$ & $<0.001$ \\
\hline Time*Warm & 0.208 & 0.272 & 0.354 & 0.058 \\
\hline Temperature & $<0.001$ & $<0.001$ & $<0.001$ & $<0.001$ \\
\hline Time*Temp & $<0.001$ & 0.036 & 0.735 & 0.362 \\
\hline Warm*Temp & 0.001 & $<0.001$ & 0.571 & 0.059 \\
\hline Time*Warm*Temp & 0.192 & 0.342 & 0.647 & 0.162 \\
\hline \multicolumn{5}{|c|}{ Spring budbreak } \\
\hline Season & 0.001 & 0.002 & $<0.001$ & $<0.001$ \\
\hline Warm & 0.426 & 0.032 & $<0.001$ & 0.075 \\
\hline Season*Warm & 0.667 & 0.081 & 0.090 & 0.009 \\
\hline
\end{tabular}




\section{Figure captions}

Figure 1. Daily maximum and minimum temperatures for Sault Ste. Marie, Ontario, from September 2013 to May 2014 (Environment Canada online archive at http://climate.weather.gc.ca).

Figure 2. Relative conductivity (least square means $\pm \mathrm{SE}$ ) (measured at different test temperatures) of black spruce (a), white spruce (b), jack pine (c), and lodgepole pine (d) in November, immediately after warming (left) and after 10 and 20 days following cold storage at $4^{\circ} \mathrm{C}$ subsequent to warming (middle and right). The symbol $*$ indicates significant differences at $\mathrm{p}<0.05$ among warming treatments at a specific test temperature. Needles that were apparently damaged after freezing tests are shown with filled symbols.

Figure 3. Relative conductivity (least square means $\pm \mathrm{SE}$ ) (measured at different test temperatures) of black spruce (a), white spruce (b), jack pine (c), and lodgepole pine (d) in January, immediately after warming (left) and after 10 and 20 days following cold storage at $4^{\circ} \mathrm{C}$ subsequent to warming (middle and right). The symbol * indicates significant differences at $\mathrm{p}<0.05$ among warming treatments at a specific test temperature. Needles that were apparently damaged after freezing tests are shown with filled symbols.

Figure 4. Relative conductivity (least square means $\pm \mathrm{SE}$ ) (measured at different test temperatures) of black spruce (a), white spruce (b), jack pine (c), and lodgepole pine (d) in March, immediately after warming (left) and after 10 and 20 days following cold storage at $-4^{\circ} \mathrm{C}$ subsequent to warming (middle and right). The symbol * indicates significant differences at 
$\mathrm{p}<0.05$ among warming treatments at a specific test temperature. Needles that were apparently damaged after freezing tests are shown with filled symbols.

Figure 5. Thermal requirement for budbreak (least square means $\pm \mathrm{SE}$; thermal accumulation during warming is not included) of (a) black spruce, (b) white spruce, (c) jack pine, and (d) lodgepole pine (cumulative growing degree hours $>0{ }^{\circ} \mathrm{C}$ ) in spring under $20{ }^{\circ} \mathrm{C}\left(\right.$ day) $/ 10{ }^{\circ} \mathrm{C}$ (night) and a 16-h photoperiod, following experimental warming in different winter months, November, January, and March. Means with different letters at a specific seasonal period differ significantly at $\mathrm{p}<0.05$. 


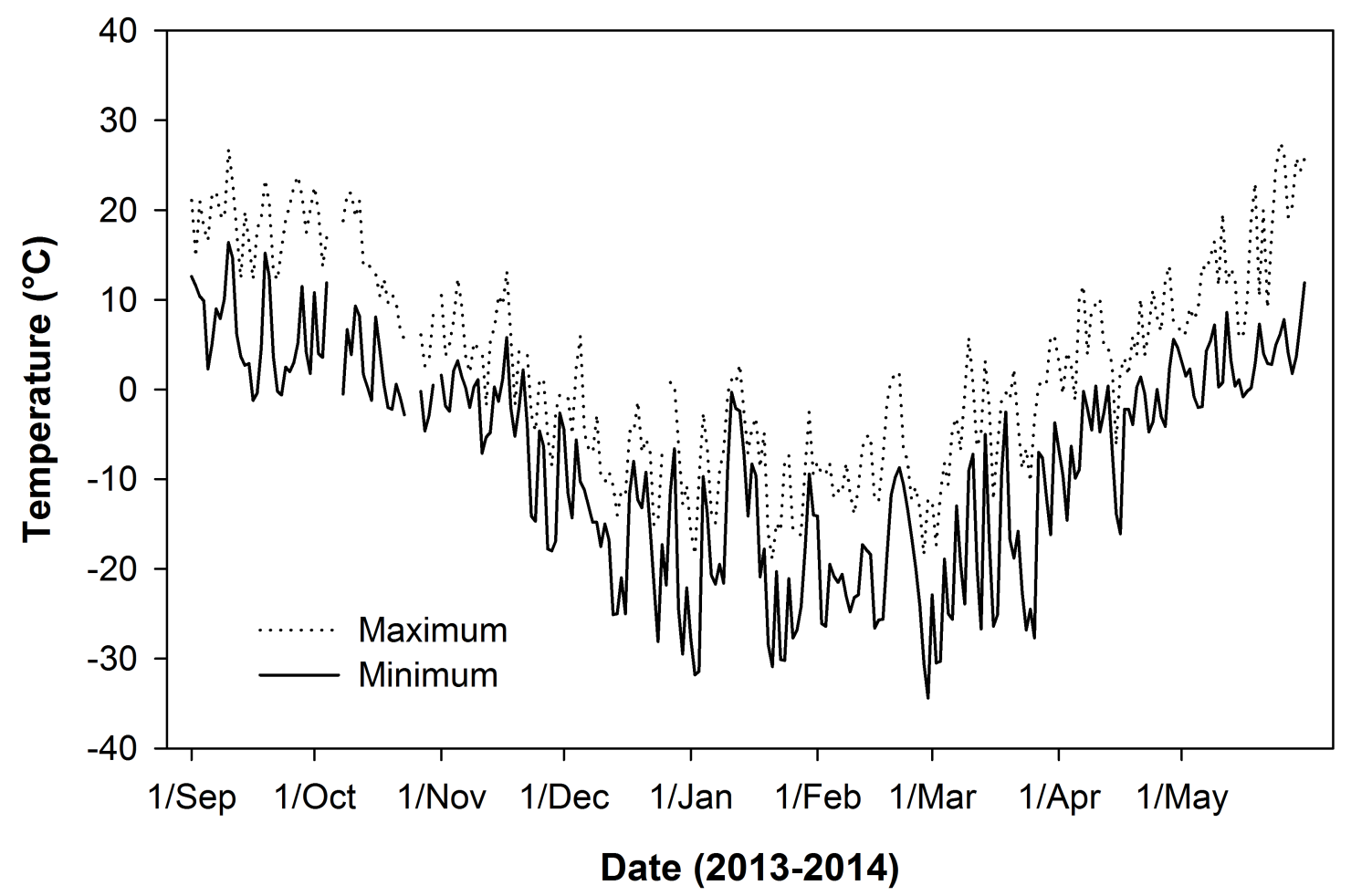




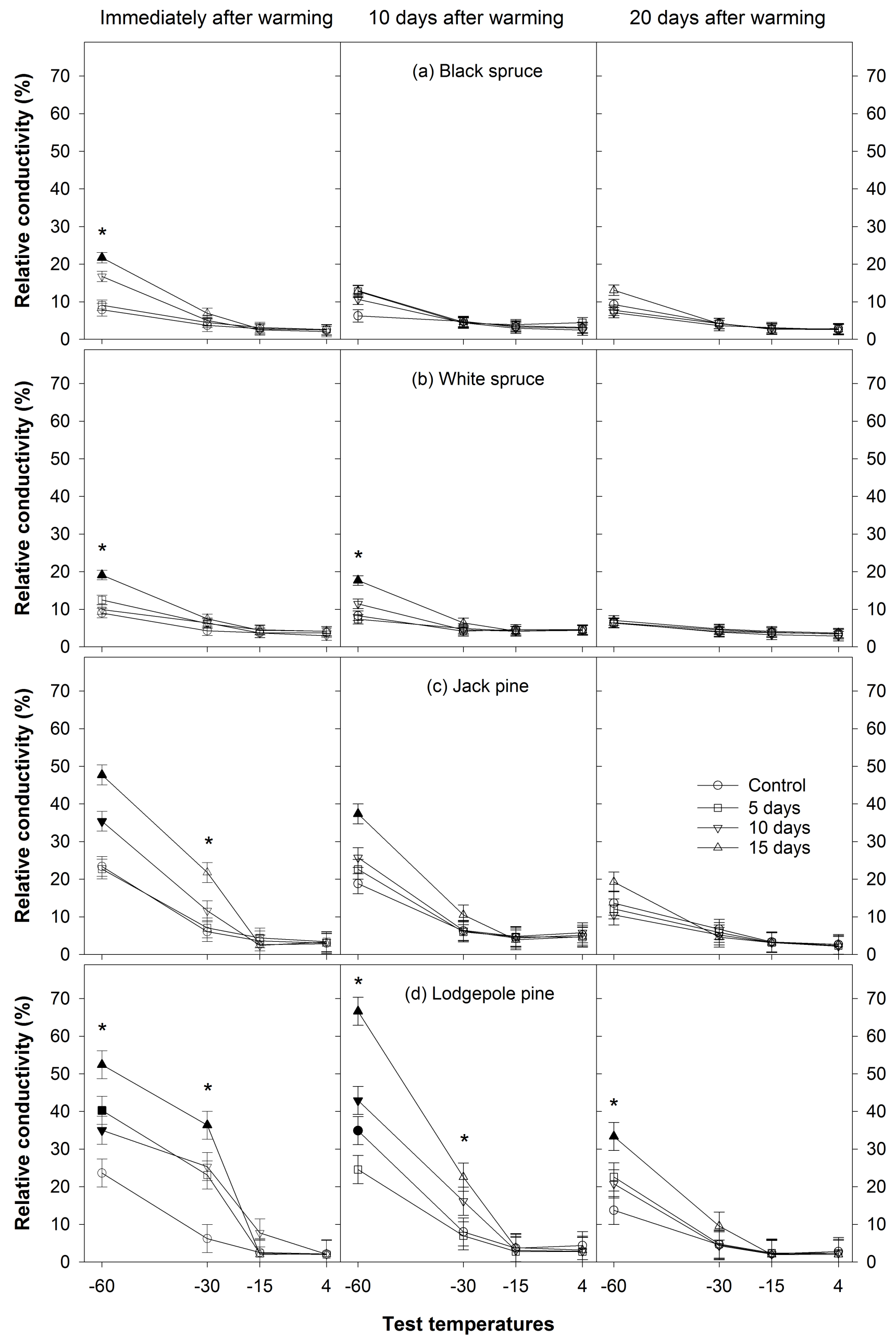

https://mc06.manuscriptcentral.com/botany-pubs 


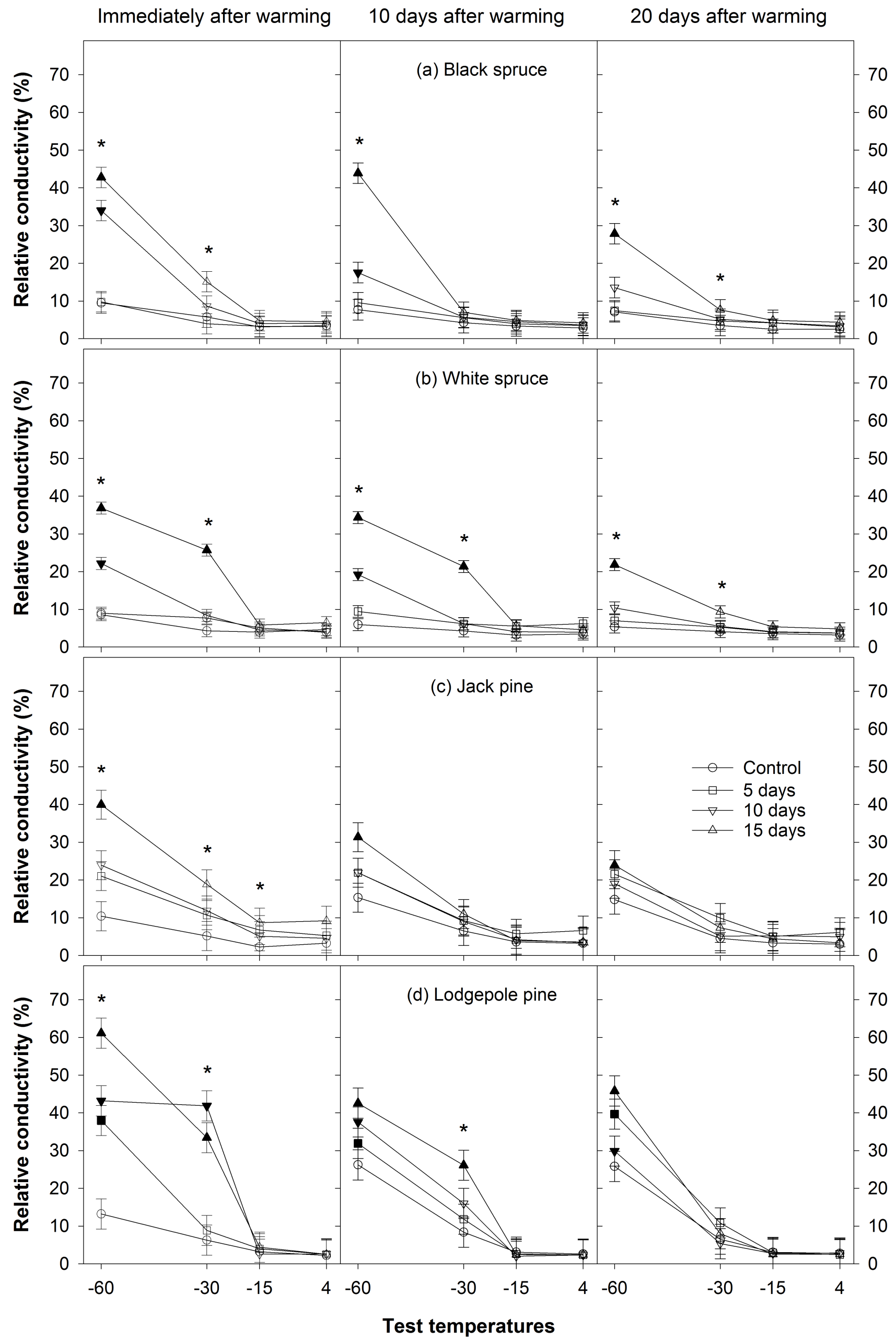

https://mc06.manuscriptcentral.com/botany-pubs 


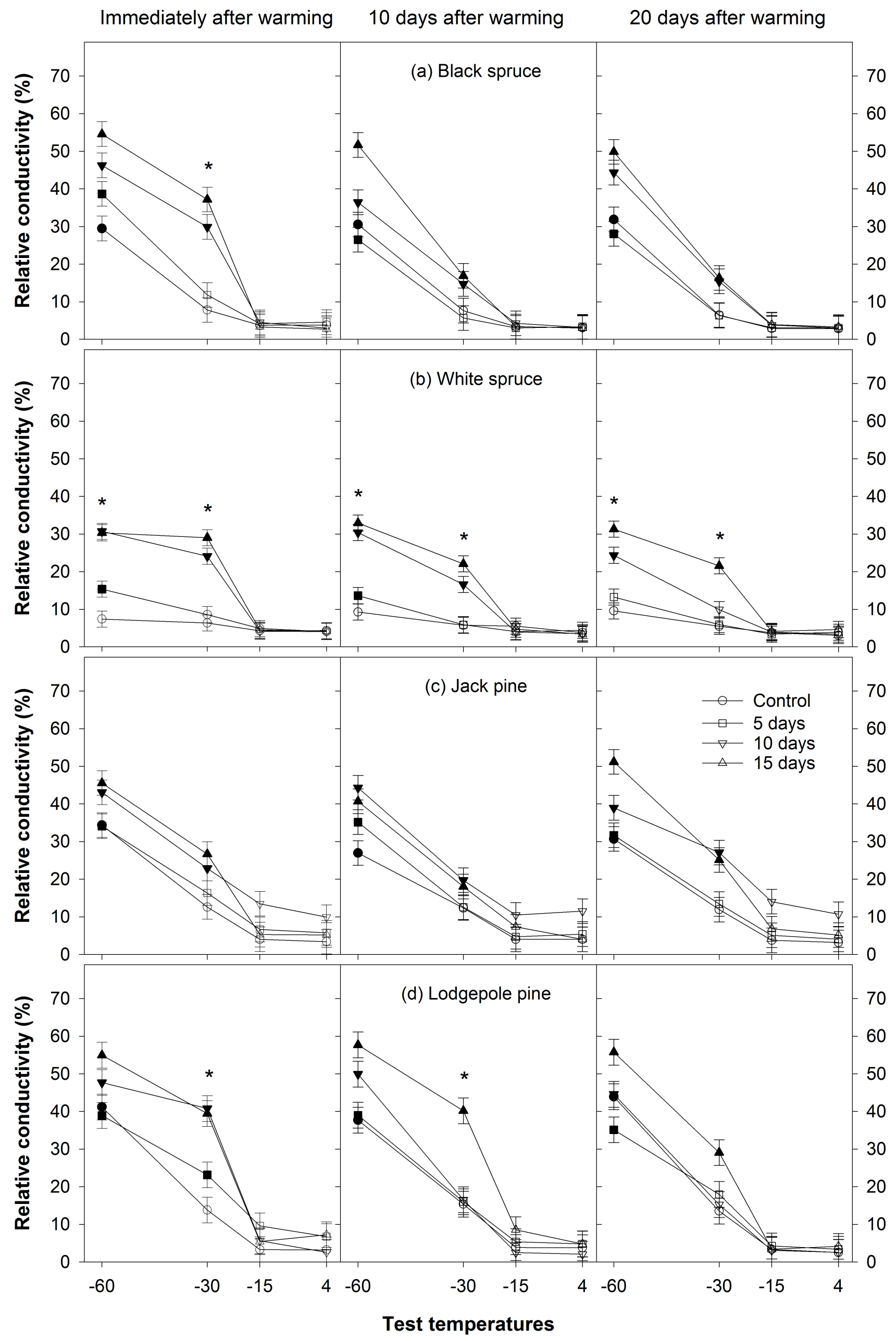

https://mc06.manuscriptcentral.com/botany-pubs 


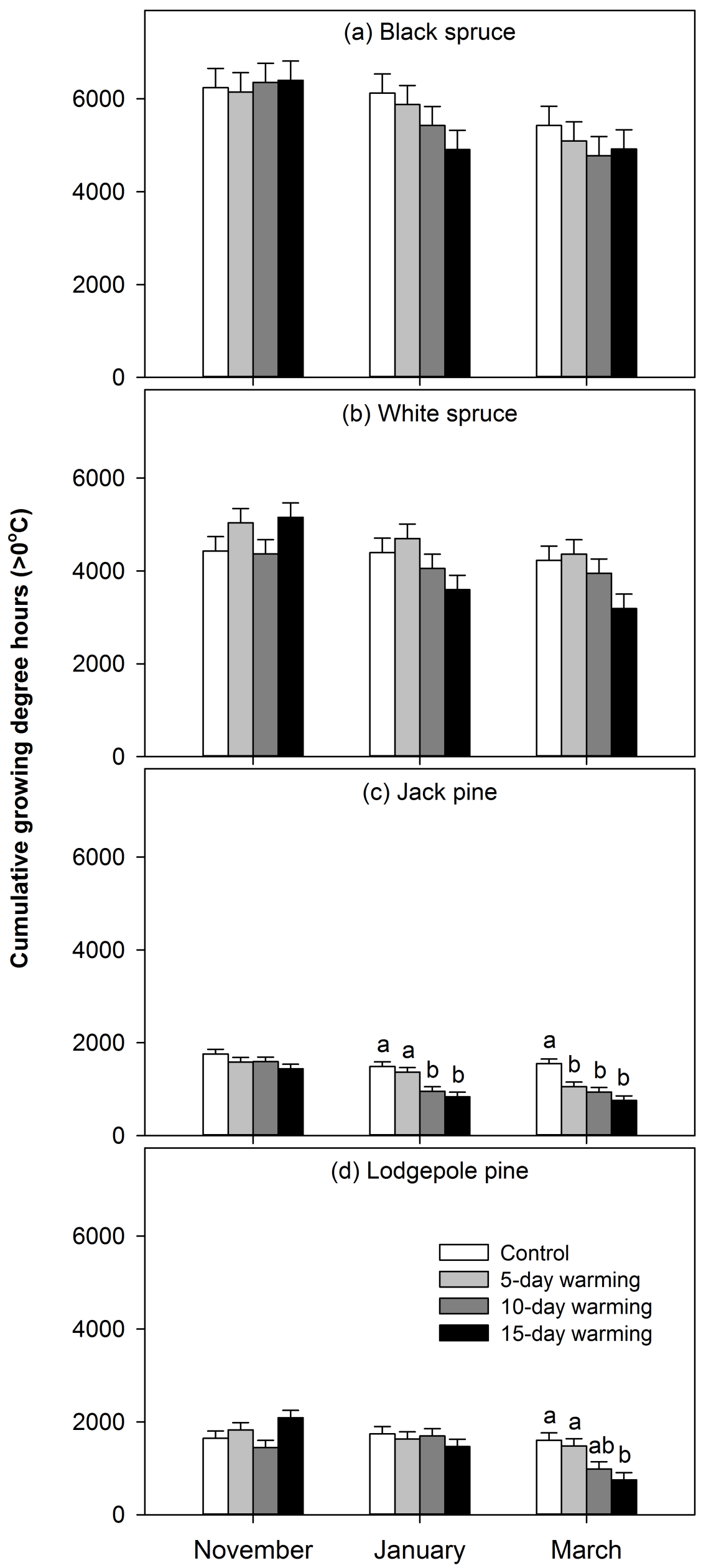

